\title{
Corrosion Fatigue Behavior of Cold-Worked 304L Stainless Steel in a Simulated BWR Coolant Environment
}

\author{
M. C. Young*, J. Y. Huang and R. C. Kuo \\ Institute of Nuclear Energy Research (INER), P.O.Box 3-14, 1000 Wenhua Road, \\ Chiaan Village, Longtan, Taoyuan 32546, Taiwan, R.O.China
}

Fatigue crack growth tests were performed to evaluate the effect of cold work on the fatigue behavior of 304L stainless steel in the ambient air at room temperature and $300^{\circ} \mathrm{C}$ and in a simulated BWR coolant environment, respectively. The fatigue crack growth rates (FCGRs) for the as-received (AR) and cold-rolled specimens at room temperature were in the same range and the FCGRs obtained at $300^{\circ} \mathrm{C}$ in air were higher than those at room temperature. In addition, the FCGRs for the AR specimens were higher at $300^{\circ} \mathrm{C}$ in air compared with those for the coldrolled. The specimens tested in the water environment at $300^{\circ} \mathrm{C}$ showed higher corrosion fatigue crack growth rates (CFCGRs) relative to those measured in air at room temperature and $300^{\circ} \mathrm{C}$. Local quasi-cleavages could account for the observation that the FCGRs in air at $300^{\circ} \mathrm{C}$ were faster than at room temperature. The dominant fracture features of quasi-cleavages, along with corrosion products, were observed with all the 304L specimens tested in the simulated BWR water environment, which could be related to the higher crack growth rates in the corrosive environment. [doi:10.2320/matertrans.MRA2008402]

(Received October 27, 2008; Accepted December 24, 2008; Published February 25, 2009)

Keywords: AISI 304 stainless steel, corrosion fatigue crack growth rate, crack closure, water chemistry, cold roll, martensite

\section{Introduction}

Austenitic stainless steels (SSs) are extensively used for in-core and out-of-core components of nuclear power plants thanks to their superior corrosion resistance and mechanical properties. Stress corrosion cracking and corrosion fatigue are the two degradation mechanisms reported to be responsible for most of the failure cases of austenitic stainless steel components in the nuclear power plants of both boiling water reactor $(\mathrm{BWR})$ and pressurized water reactor $(\mathrm{PWR}){ }^{1-5)}$ In terms of better irradiation-induced swelling resistance and high-temperature mechanical properties, cold-worked austenitic stainless steels are often employed to suit the needs of field applications. ${ }^{6-8)}$ However, the mechanical and corrosive properties of unstable austenitic stainless steels, such as AISI 304 and 316, have been reported to change with cold work, which could be accounted for from the perspective of microstructural evolution with plastic deformation.

It is well known that the fatigue behavior of austenitic SSs is associated with the dislocation structure, martensite transformation and crack closure. The dislocation cells and wall-channels are observed near the crack tip of fatigued 316 stainless steels. $^{9-12)}$ The formation of dislocation structure plays an important role in the accumulation of plastic strain during cyclic loading. When dislocation tangles are saturated, dislocations would make planar slip which could prompt the initiation and growth of fatigue crack. ${ }^{10}$ )

Martensite transformation, dislocation pile-up and residual stress in the front of a crack tip could bring about fatigue closure, retarding the FCGR. ${ }^{13-17)}$ At a lower mean stress level, the unstable 301 SS has a lower FCGR than stable 302 SS. ${ }^{17)}$ It could be explained by the observation that the volume change by phase transformation gives rise to residual compressive stress at the plastic zone close to the crack tip. However, the cold-worked specimens of both stable and unstable SSs have the lower crack growth rates than the

*Corresponding author, E-mail: mcyoung@iner.gov.tw annealed ones. As a result, it is inferred that phase transformation could have little or no effect on FCGRs for the cold-worked specimens.

In the corrosive environments, the FCGRs of 304 stainless steel specimens with prior cold work is about 7 times higher than those for the annealed ones. ${ }^{18)}$ The twins and grain boundaries are the preferred path for crack propagation when they intercept the plane of the main crack at an anger less than 30 degrees. Therefore, the refinement of austenite grains by cold roll may not be beneficial to slow-down in corrosion fatigue crack growth. The observations of the twin and grain boundary cracking and a small amount of $\alpha^{\prime}$-martensites in the annealed stainless steels tested in the corrosive environments further imply that cyclic strain-induced $\alpha^{\prime}$-martensite is not solely responsible for environmental enhancement of crack growth. ${ }^{18)}$ Other microstructural features, such as twin and grain boundaries, slip bands, and cold work-induced lattice defects, could also play an important role. ${ }^{18)}$ But, on the other hand, the deformation-induced martensite of 304 SS in the $288^{\circ} \mathrm{C}$ pure water environment is considered to be the most important factor for accelerating SCC. ${ }^{19)}$

In the past, researches were mainly focused on the stress corrosion cracking behavior of stainless steels in simulated BWR/PWR coolant environments. ${ }^{19-23)}$ Little work on the corrosion fatigue behavior of austenitic SSs in reactor coolant environments has been reported. Hence, this work was intended to investigate the corrosion fatigue crack growth behavior of cold-worked 304L stainless steel in a simulated BWR coolant environment. Corrosion fatigue crack growth rates and possible fracture mechanisms are elucidated in this report.

\section{Experimental Procedures}

\subsection{Materials}

The chemical composition (mass\%) of AISI 304L steel plate according to the specifications of ASTM SA-240 is shown in Table 1 . The specimens were cold-rolled to $5 \%$, 
Table 1 The chemical composition of the AISI 304L steel plate.

\begin{tabular}{ccccccccccccc}
\hline $\begin{array}{c}\text { Content } \\
(\mathrm{mass} \%)\end{array}$ & $\mathrm{Ni}$ & $\mathrm{Cr}$ & $\mathrm{C}$ & $\mathrm{Si}$ & $\mathrm{Mn}$ & $\mathrm{Co}$ & $\mathrm{S}$ & $\mathrm{Cu}$ & $\mathrm{P}$ & $\mathrm{Mo}$ & $\mathrm{Fe}$ \\
\hline $304 \mathrm{~L}$ & 8.81 & 18.1 & 0.022 & 0.5 & 1.56 & 0.1 & 0.0004 & 0.48 & 0.03 & 0.28 & $\mathrm{Bal}$. \\
\hline
\end{tabular}
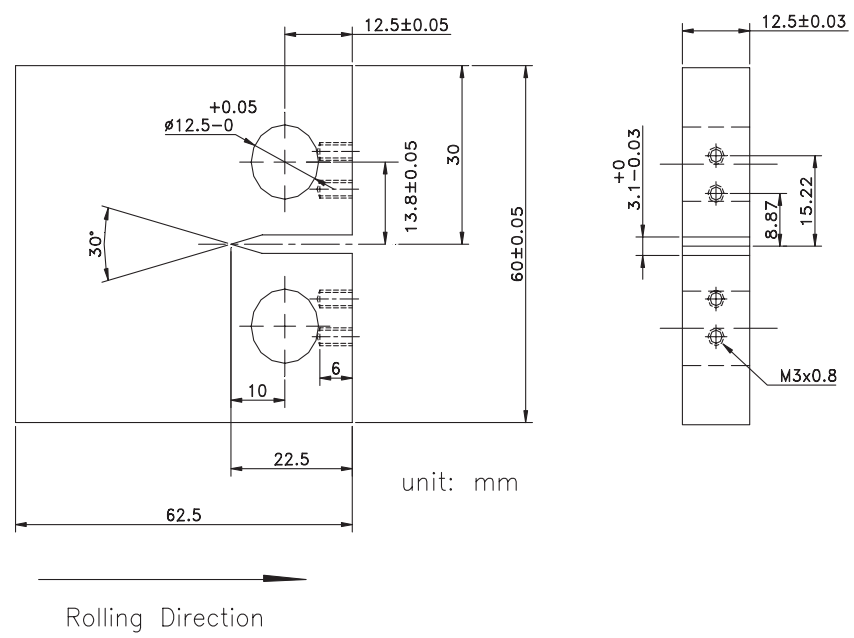

Fig. 1 Schematic diagram showing the dimensions of compact tension specimen.

$10 \%, 20 \%$, and $30 \%$ reductions in thickness. Electrochemical etching in 10 mass $\% \mathrm{H}_{2} \mathrm{C}_{2} \mathrm{O}_{4} \cdot 2 \mathrm{H}_{2} \mathrm{O}$ solution was utilized to reveal the microstructures of the as-received (AR) and cold-rolled (CR) specimens of various reductions. Tensile properties of the AR and CR steel plates were conducted at room temperature $(\mathrm{RT})$ and $300^{\circ} \mathrm{C}(\mathrm{HT})$.

\subsection{Fatigue crack growth rate tests}

According to the ASTM E 647 specifications, compacttension type (CT) specimens with a thickness of $12.5 \mathrm{~mm}$ and a width of $50 \mathrm{~mm}$ were machined, as shown in Fig. 1. Before fatigue testing, all specimens were lightly polished with emery paper to \#600. The specimens were pre-cracked by cyclic loading with decreasing $\Delta \mathrm{K}$ (stress intensity factor range), at a load ratio $(\mathrm{R}, \mathrm{Pmin} / \mathrm{Pmax})$ of 0.1 , till a precracked length of $3 \mathrm{~mm}$ and $\Delta \mathrm{K}$ of $12 \mathrm{MPa} \sqrt{m}$ were reached. Based on the elastic compliance principle, a capacitance-type COD gauge was used to measure the fatigue crack length at room temperature and $300^{\circ} \mathrm{C}$ in air. The test frequency in air was $20 \mathrm{~Hz}$. The corrosion fatigue tests were conducted on a closed-loop, servo-electric machine with a water circulation loop under load control and at a frequency of $0.02 \mathrm{~Hz}$. The constant load amplitude was set at an $\mathrm{R}$ ratio $\left(\mathrm{Load}_{\min } / \mathrm{Load}_{\max }\right)$ of 0.1 by an inner load cell control, which deducted the friction force between the pulling rod and the sealing material. The external load cell measurements including the friction force were also monitored for a comparison with the ones taken by the inner load cell. The filtered air was injected into the water tank to maintain a saturated oxygen level in the water environment. The conditions of the water environment are summarized in Table 2. The crack length was measured by an ACPD technique. The final fatigue crack length measurement was further calibrated against the average value of five measure-
Table 2 Test conditions of high-temperature water environment.

\begin{tabular}{cc}
\hline Test parameters & $\begin{array}{c}\text { Air-saturated } \\
\text { (with filtered air) }\end{array}$ \\
\hline Pressure, $\mathrm{MPa}$ & 10 \\
Temperature, $^{\circ} \mathrm{C}$ & 300 \\
Conductivity(inlet), $\mu \mathrm{Scm}^{-1}$ & 0.08 \\
Conductivity(outlet), $\mu \mathrm{Scm}^{-1}$ & 0.151 \\
Oxygen(inlet), $\mathrm{ppm}$ & 7.4 \\
Oxygen(outlet), $\mathrm{ppm}$ & 6.7 \\
ECP(SHE), volt & 0.2 \\
pH(inlet) & 5.95 \\
pH(outlet) & 6.17 \\
Autoclave exchange rate, time $/ \mathrm{h}$ & 1 \\
\hline
\end{tabular}

ments taken along the crack front on the fracture surface by a microscope at a magnification of 20 according to ASTM E 647 .

It was known that martensite transformation of unstable stainless steels can be induced by plastic deformation or fatigue process. Ferrite meter was utilized by magnetic technique to determine the average martensite content of the cold-rolled specimens and fatigue-fractured surface. In addition, fractographic features of fatigued specimens were examined by a Hitachi 4800 scanning electron microscope (SEM), with emphasis on specimens showing changes in fracture modes in various environments.

\section{Results and Discussion}

\subsection{Metallographic features}

The microstructures of the cold-rolled 304L SS plates with various reductions are shown in Fig. 2. Equiaxial austenite grains with annealed twins were found in the AR specimen matrix. The cold-rolled specimens showed needle and band structures within deformed grains which were introduced by the cold roll process. The amounts of needle grains increased with increasing the cold roll reduction degree. The microstructure of the cold-rolled specimen with $30 \%$ reduction (CR30) exhibited noticeable band structure.

The martensite transformation was induced by the cold roll process. The magnetic measurements of martensite in the cold-rolled specimens of different reductions were conducted by a ferrite scope. As shown in Fig. 3, the martensite content increased as the cold roll degree increased.

Figure 4 shows the hardness values of the specimens coldrolled to different degrees. Owing to strain hardening and an increment in martensitic phase, the hardness value increased as the cold roll reduction increased. In addition, the hardness measurements taken near the surfaces of the cold-rolled specimens with higher degrees of deformation were higher than those taken around the center.

\subsection{Tensile properties in air at room temperature and $300^{\circ} \mathrm{C}$}

Figure 5 shows the tensile properties of the specimens cold-rolled to different degrees at room temperature and $300^{\circ} \mathrm{C}$. The yield strength (YS) and ultimate tensile strength (UTS) at $300^{\circ} \mathrm{C}$ were lower than those at room temperature. The percentages within parentheses indicate the reductions 

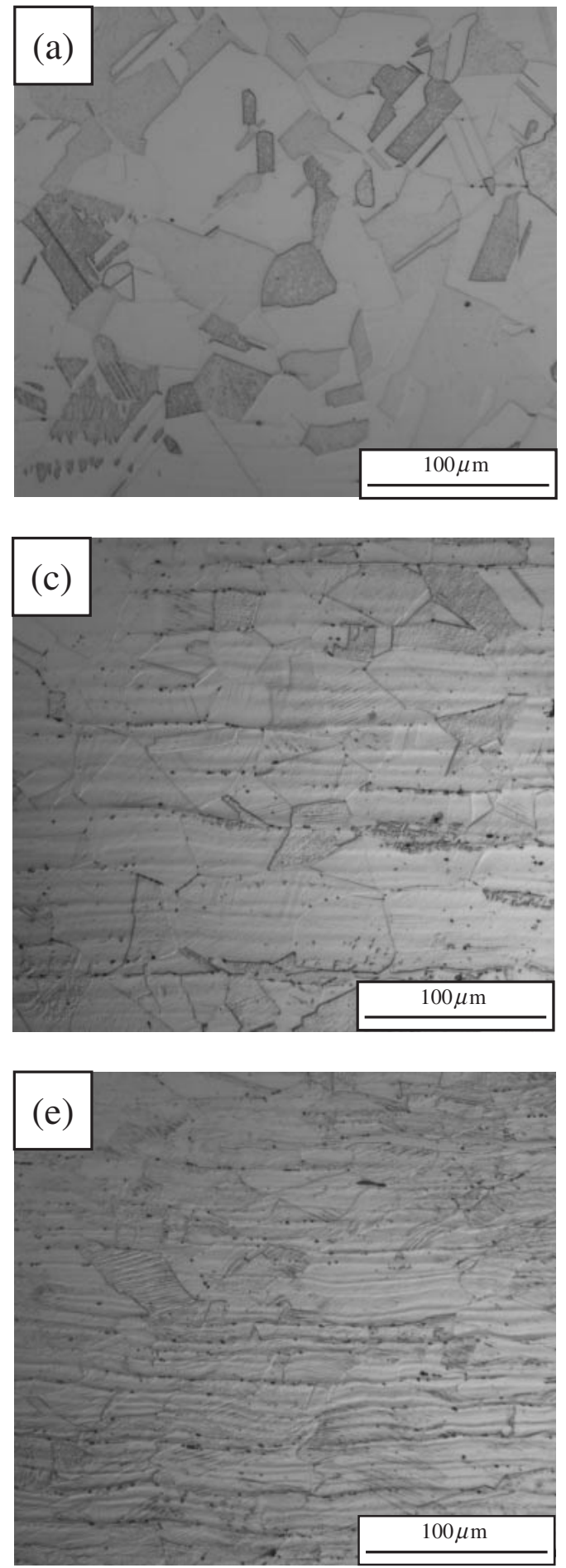
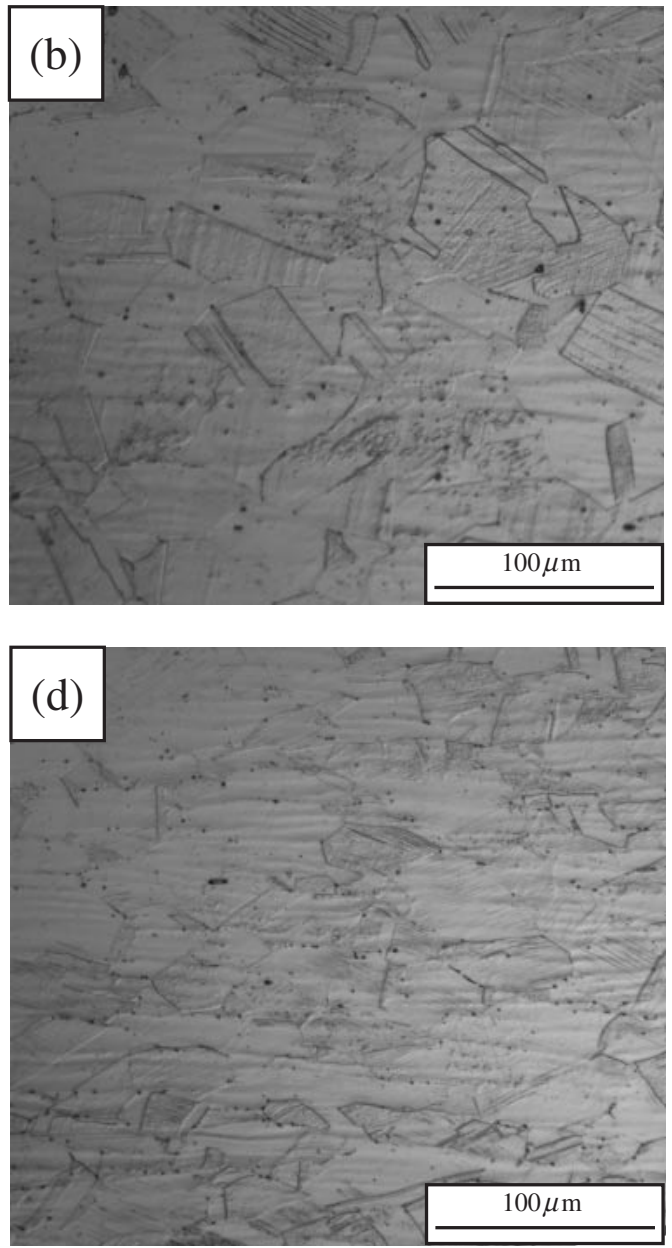

Fig. 2 Metallographs revealing the microstructure of the 304L austenitic SSs with different cold roll reductions, (a) BM, (b) 5\%, (c) 10\%, (d) $20 \%$, (e) $30 \%$ specimens.

in YS and UTS at $300^{\circ} \mathrm{C}$ relative to those at room temperature. Both at $300^{\circ} \mathrm{C}$ and room temperature, YS and UTS increased as the cold roll deformation increased. A larger reduction in ductility of all $\mathrm{CR}$ specimens relative to the AR specimen was noticed.

3.3 Fatigue crack growth rate measurements for coldrolled 304L SS specimens in the ambient air and a simulated BWR coolant environment

The fatigue crack growth behavior of cold-rolled speci- mens in different environments is shown in Fig. 6. In the region of $\Delta \mathrm{K}>20 \mathrm{MPa} \sqrt{m}$, the fatigue crack growth rates (FCGRs) of the cold-rolled specimens at room temperature were almost identical. As shown in Fig. 6(a), 20\% and 30\% cold-rolled specimens had lower FCGRs in the lower $\Delta \mathrm{K}$ region. A previous study ${ }^{17)}$ reported that deformation induced martensite transformation occurred with unstable stainless steels during the fatigue crack growth process. The volume of martensitic phase is larger than austenite phase, which leads to fatigue crack closure and retards FCGR. More 


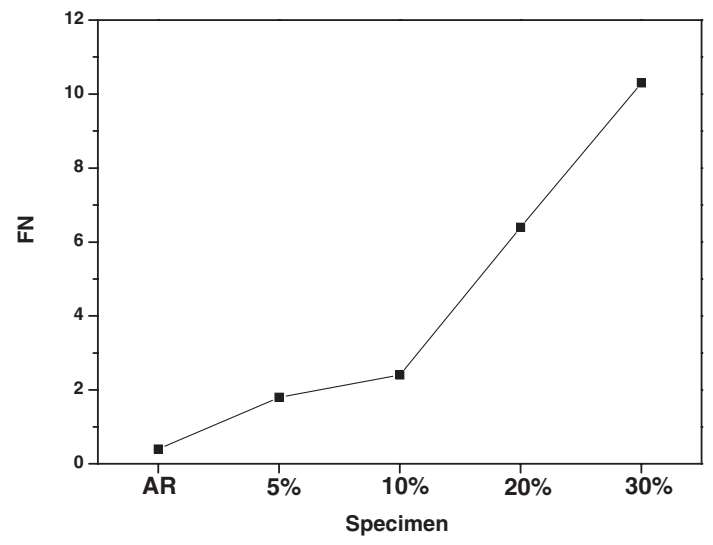

Fig. 3 The amount of martensite in terms of ferrite number (FN) versus 304L SSs with different degrees of cold roll.

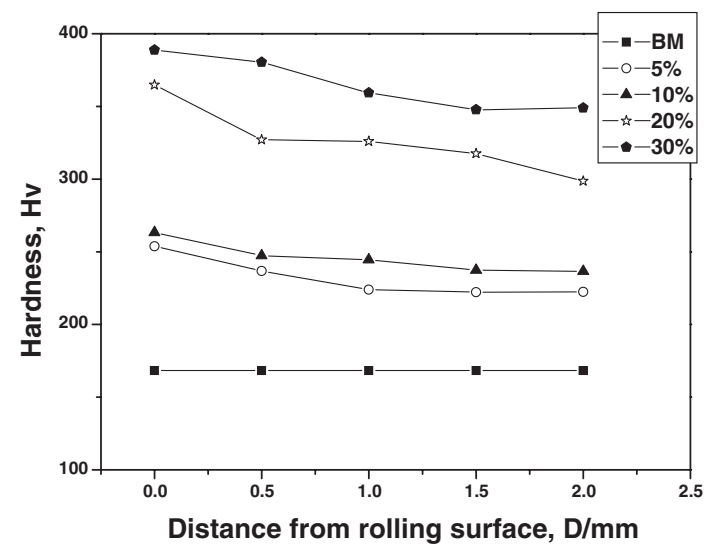

Fig. 4 The hardness measurements of 304L SSs with distance from the rolling surface.

fatigue crack closure was expected to occur in the $20 \%$ and $30 \%$ cold-rolled specimens, which was a consequence of more transformed martensite phases. On the contrary, AR specimen has better plasticity than the CR ones. Plasticityinduced closure is easier to occur with AR specimen. As a result, the AR specimen showed lower FCGR than 5\% and $10 \%$ cold-rolled specimens in the low $\Delta \mathrm{K}$ region.

The FCGR behavior of the cold-rolled specimens at $300^{\circ} \mathrm{C}$ in air is shown in Fig. 6(b). Generally, UTS and YS of 304L stainless steels decreased with increasing the testing temperature. Figure 5(a) shows that a decrease in YS between room temperature and $300^{\circ} \mathrm{C}$ is more significant for the $\mathrm{AR}$ specimen than for the cold-rolled spcimens. Hence, the AR specimens at $300^{\circ} \mathrm{C}$ in air showed higher FCGR than the cold-rolled ones. Previous studies further demonstrated that no deformation-induced martensite appeared at higher $\mathrm{Md}$ temperatures. ${ }^{24,25}$ ) The martensite measurement results, Fig. 7, substantiate that no martensite phase transformation occurred during the fatigue crack growth tests in air at $300^{\circ} \mathrm{C}$. No crack closure effect due to phase transformation was observed. Therefore, the FCGRs of all cold-rolled specimens with different degrees of reduction showed the same characteristics at $300^{\circ} \mathrm{C}$.

The corrosion fatigue crack growth rates (CFCGRs) of cold-rolled specimen in water at $300^{\circ} \mathrm{C}$ were slower
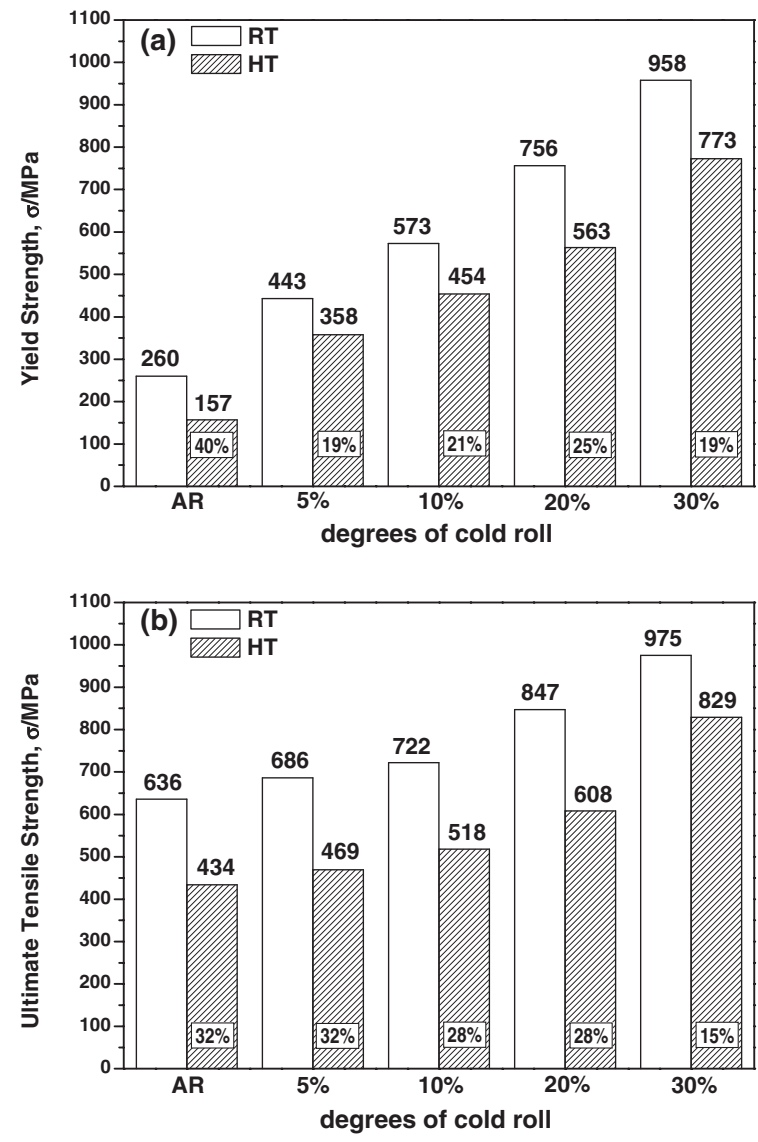

Fig. 5 Tensile properties of the 304L SSs with different degrees of cold roll in air at room temperature and $300^{\circ} \mathrm{C}$, (a) yield strength (YS), (b) ultimate tensile strength (UTS). The percentage within parentheses indicated the loss of strength at $300^{\circ} \mathrm{C}$ in air relative to that at room temperature in air.

compared with AR specimens, Fig. 6(c). But there was no discernible difference observed between the CFCGR behavior of the cold-rolled specimens with different reductions. The AR specimen showed much faster crack growth rates in the water environment at $300^{\circ} \mathrm{C}$ when $\Delta \mathrm{K}$ was higher than $45 \mathrm{MPa} \sqrt{m}$.

\subsection{The environmental effect on fatigue crack growth rate}

Figure 8 shows the fatigue characteristics of AR and $20 \%$ cold-rolled specimens in various environments. When $\Delta \mathrm{K}=30 \mathrm{MPa} \sqrt{m}$, the CFCGR of the AR specimen in water at $300^{\circ} \mathrm{C}$ was an order of magnitude higher than in air at RT and $300^{\circ} \mathrm{C}$. The film-rupture could be an important mechanism affecting the CFCGR. ${ }^{26)}$ The fresh surface metal was exposed to corrosive environment and retarded the crack propagation. Fatigue crack propagated forward when film was ruptured by cyclic loading and corrosion. The corrosion products on the surface of the specimens tested in water at $300^{\circ} \mathrm{C}$ will be reported in the later section. It suggested that corrosion occurred during fatigue crack growth in water at $300^{\circ} \mathrm{C}$, which promoted the film rupture. Therefore, the corrosion fatigue crack growth rates in water at $300^{\circ} \mathrm{C}$ were obviously faster than in air at room temperature and at $300^{\circ} \mathrm{C}$. 

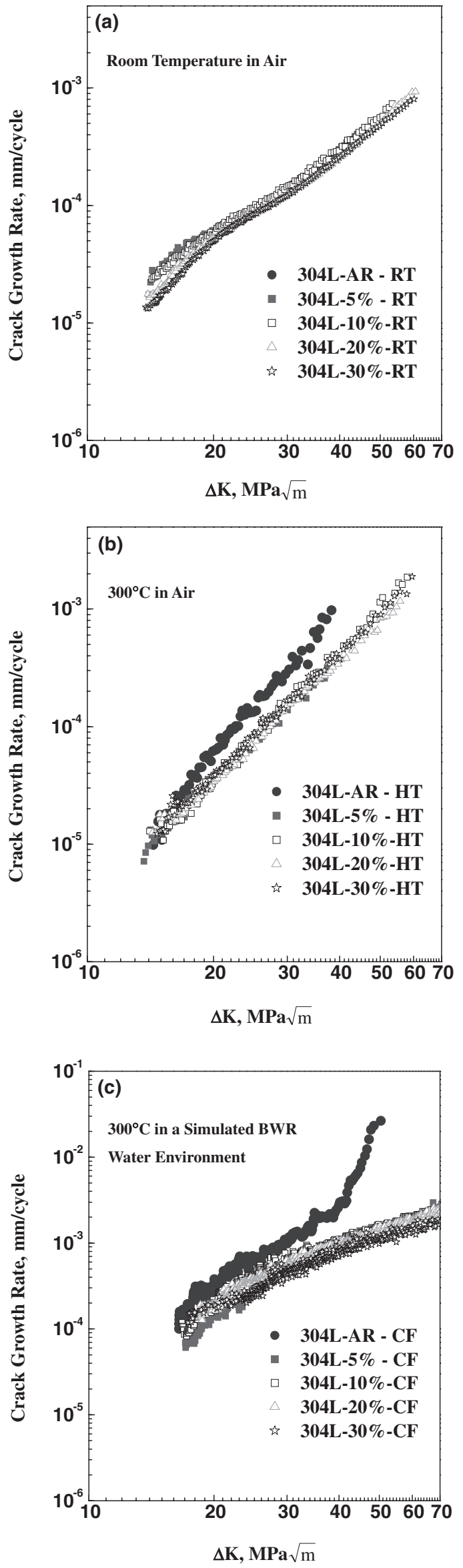

Fig. 6 The da/dN versus $\Delta \mathrm{K}$ curves for $304 \mathrm{~L}$ austenitic stainless steel specimens with different cold roll reductions, (a) at room temperature in air, (b) at $300^{\circ} \mathrm{C}$ in air, and (c) in $300^{\circ} \mathrm{C}$ water environment.
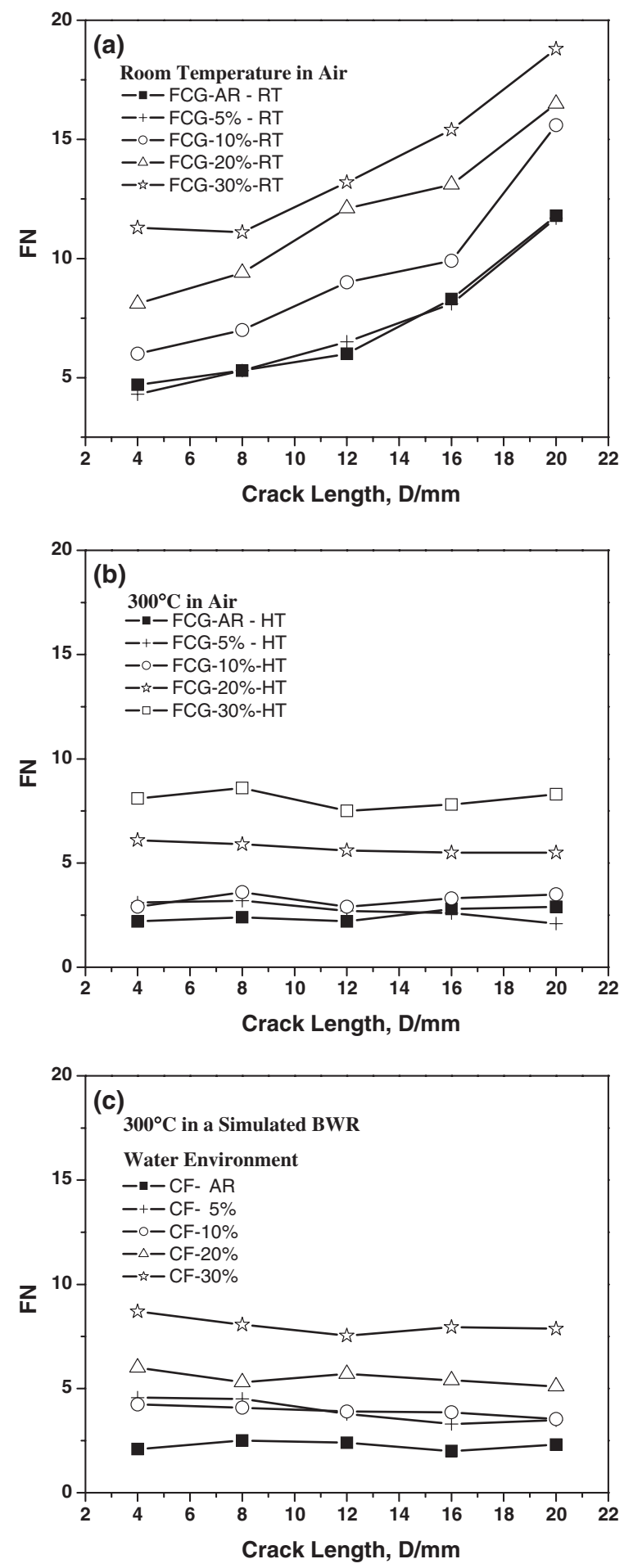

Fig. 7 The amount of martensite around the fatigue-fractured surface in terms of ferrite number (FN) versus crack length $(\mathrm{mm})$, (a) at room temperature in air, (b) at $300^{\circ} \mathrm{C}$ in air, and (c) in $300^{\circ} \mathrm{C}$ water environment.

The tensile strength, martensite content, residual stress and dislocation density of cold-rolled 304L SS were different from those for the AR specimens. The cold-rolled specimens had higher yield strengths, hence showed slower fatigue crack rates at $300^{\circ} \mathrm{C}$ in air and water environment than AR ones. The martensite phase might be introduced during the cold roll process or fatigue crack growth test. The results of martensite measurement are shown in Fig. 7. The fatigue tests in the water environment were performed 


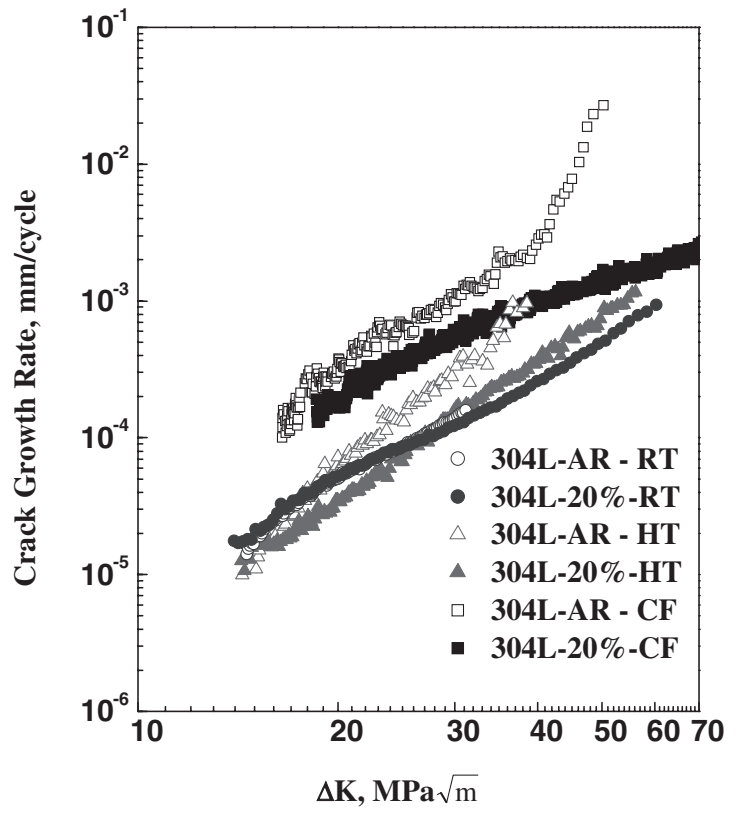

Fig. 8 The da/dN versus $\Delta \mathrm{K}$ curves for $304 \mathrm{~L}$ austenitic stainless steel specimens with AR and $20 \%$ cold rolled specimens in various environments.

at $300^{\circ} \mathrm{C}$ that was higher than $\mathrm{Md}$ temperature for austenitic stainless steels. Hence no martensite phase could be transformed by the corrosion fatigue process. All martensite content of cold-rolled specimens was introduced by prior cold roll and the fatigue behavior was influenced with both austenite and martensite phases. The residual stress might induce crack closure and retard crack propagation. The martensite phase transformation during the corrosion fatigue process was not observed, so the residual stress due to phase transformation was not expected. The residual stress in the cold-rolled specimen was mainly produced by the cold roll process. It is demonstrated that the dislocation density is the controlling factor for corrosion pit initiation and propagation in corrosive environment. ${ }^{27)}$ The corrosion fatigue crack growth rates in $300^{\circ} \mathrm{C}$ water could be influenced by the dislocation densities of the specimens tested. Although the martensite content, residual stress, dislocation density and tensile strength of all specimens with different amounts of cold roll reduction were different, the CFCGRs were similar. It suggested that the degree of cold roll reduction was not a significant factor for the corrosion fatigue behavior.

\subsection{Fractographic observations for fatigue-tested speci- mens}

Figure 9 shows the SEM fractographs of the 304L coldrolled specimens fatigue-tested in air and water. As shown in Fig. 9(a), a mixture of transgranular fatigue fracture features and flat facets were observed in the AR and all the cold-rolled specimens tested in air at room temperature, a contrast to the dominant feature of quasi-cleavages in air at $300^{\circ} \mathrm{C}$ as exemplified in Fig. 9(b). Local quasi-cleavages
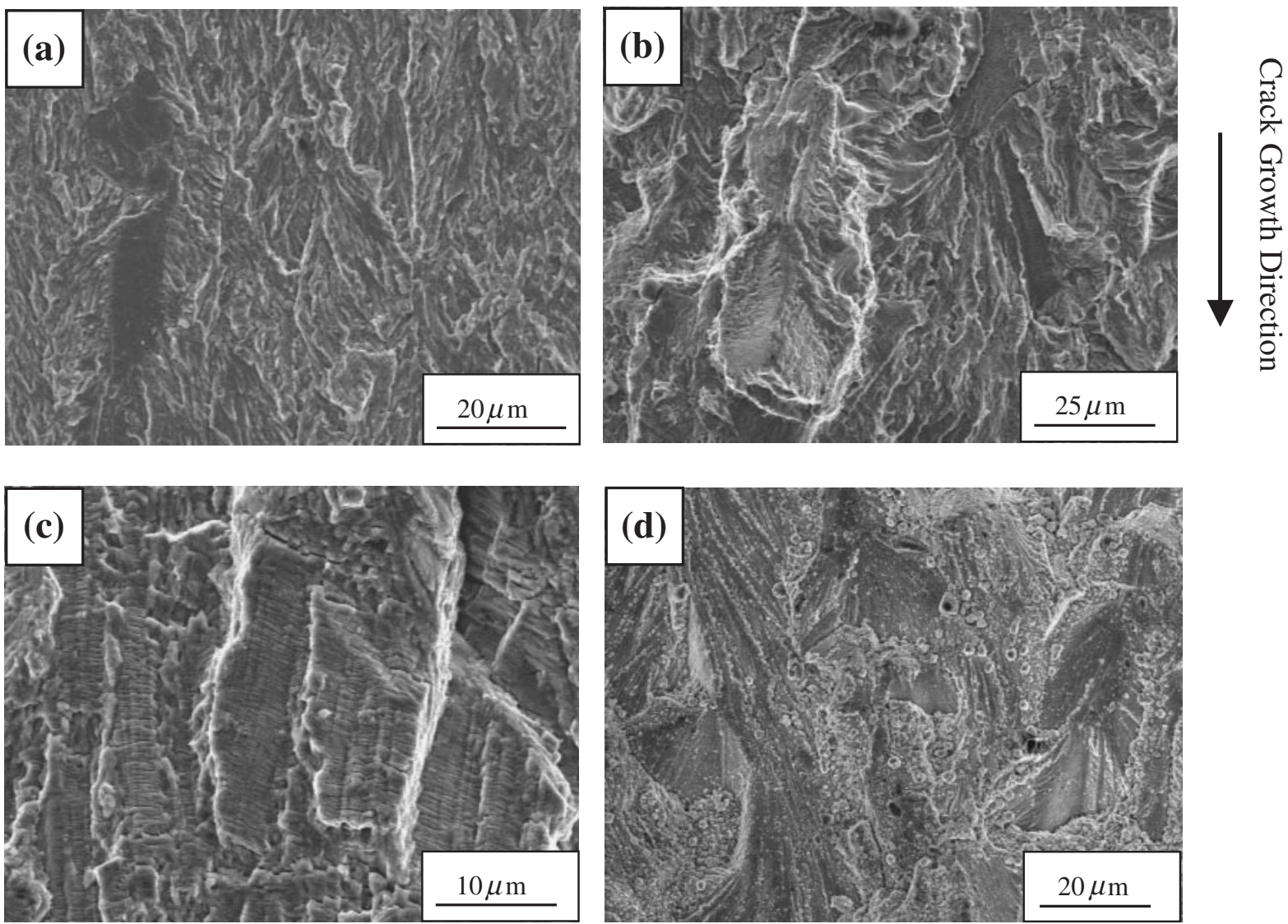

Fig. 9 Fatigue fracture features of 304L austenitic SSs with different cold roll reductions, (a) 30\% CR specimen in air at room temperature, (b) $10 \% \mathrm{CR}$ specimen in air at $300^{\circ} \mathrm{C}$, (c) $30 \% \mathrm{CR}$ specimen in air at $300^{\circ} \mathrm{C}$, (d) $\mathrm{AR}$ specimen in water environment at $300^{\circ} \mathrm{C}$. 
could account for an increase in the FCGR of 304L SSs in air at $300^{\circ} \mathrm{C}$, which explained why the FCGRs in air at $300^{\circ} \mathrm{C}$ were faster than at room temperature. The formation of flat facets had been related to the crack growth along the twin boundaries or austenite grain boundaries. ${ }^{18,28-30)}$ In addition, the fatigue striations were the prevalent features on the fracture surface of 30\% CR specimens, Fig. 9(c). Quasicleavages were also observed with all of the 304L specimens tested in water at $300^{\circ} \mathrm{C}$, and $\mathrm{AR}$ specimens had a larger proportion of qusai-cleavage features, Fig. 9(d). Besides quasi-cleavages, there were many corrosion products identified on the fracture surfaces of the specimens tested in the water environment at $300^{\circ} \mathrm{C}$. As illustrated in the last section, the corrosion promoted the film rupture, and accelerated the crack propagation in water at $300^{\circ} \mathrm{C}$. Hence, the presence of quasi-cleavages and corrosion products suggests that the 304L SS around the fatigue crack tip corroded in the simulated BWR coolant environment, and that these characteristics could be related to higher crack growth rates in the water at $300^{\circ} \mathrm{C}$.

\section{Conclusion}

(1) The FCGRs for all cold-rolled specimens at room temperature were in the same range and the FCGR for all specimens at $300^{\circ} \mathrm{C}$ in air were higher than at room temperature. The cold-rolled specimens had higher yield strengths, hence the fatigue crack rate at $300^{\circ} \mathrm{C}$ in air and water environment was slower than AR ones. With the film-rupture mechanism, the CFCGRs in water at $300^{\circ} \mathrm{C}$ were obviously faster. Although the martensite content, residual stress, dislocation density and tensile strength of all specimens with different amounts of cold roll reductions were different, the CFCGRs were similar.

(2) Fractographic features of AR and cold-rolled specimens tested at room temperature in air consisted of mainly transgranular and flat facets fatigue fractures, contrast to the dominant feature of quasi-cleavages in air at $300^{\circ} \mathrm{C}$. Facture features of local quasi-cleavages explained why the FCGRs at $300^{\circ} \mathrm{C}$ were faster than at room temperature in air environment. Dominant quasicleavages and corrosion products were observed on the fatigue surfaces of all the $304 \mathrm{~L}$ specimens tested in water at $300^{\circ} \mathrm{C}$, which could be related to higher crack growth rates in the corrosive environment.

\section{Acknowledgments}

The authors would like to acknowledge the financial support from the Institute of Nuclear Energy Research, Taiwan.

\section{REFERENCES}

1) T. M. Angeliu: Proc. 10th int. conf. on environmental degradation of materials in nuclear power system-water reactors, ed. by F. P. Ford, G. S. Was and J. L. Nelson, (TMS, 2001).

2) R. P. Shogan and T. R. Mager: Proc. 10th int. conf. on environmental degradation of materials in nuclear power system-water reactors, ed. by F. P. Ford, G. S. Was and J. L. Nelson, (TMS, 2001).

3) R. M. Horn, G. M. Gordon, F. P. Ford and R. L. Cowan: Nucl. Eng. Design 17 (1997) 313-325.

4) H. D. Solomon, C. Amzallag, A. J. Vallee and R. E. Delair: Proc. 12th int. conf. on environmental degradation of materials in nuclear power system-water reactors, ed. by T. R. Allen, P. J. King and L. Nelson, (TMS, 2005) 1083-1089.

5) B. K. Kim, H. Cho, I. S. Kim, C. H. Jang, B. S. Kim and S. C. Byeon: Proc. int. conf. in water chemistry of nuclear reactor systems, (the Korea Atomic Energy Research Institute and the Korean Nuclear Society, 2006).

6) S. G. Hong, S. Yoon and S. B. Lee: Int. J. Fati. 25 (2003) 1293-1300.

7) S. Ukai and T. Uwaba: J. Nucl. Mater. 317 (2003) 93-101.

8) R. Sandhya, K. Bhanu Sankara Rao, S. L. Mannan and R. Devanathan: Int. J. Fati. 23 (2001) 789-797.

9) W. Y Maeng and M. H. Kim: J. Nucl. Mater. 282 (2000) 32-39.

10) Y. Murase, Johsei Nagakawa and N. Yamamoto: J. Nucl. Mater. 322 (2003) 249-254.

11) Y. Oda and H. Noguhi: Int. J. Fract. 132 (2005) 99-113.

12) Y. Aoki, K. Kawamoto, Y. Oda, H. Noguchi and K. Higashida: Int. J. Fract. 133 (2005) 277-288.

13) F. O. Riemelmoser and R. Pippan: Mater. Sci. Eng. A 234-236 (1997) 135-137.

14) H. R. Mayer, S. E. Stanzl-Tschegg, Y. Sawaki, M. Hühner and E. Hornbogen: Fati. Fract. Eng. Mat. Struct. 18 (1995) 935-948.

15) P. S. Song and G. L. Sheu: Int. J. Pressure Vessel Piping 79 (2002) 725-733.

16) A. Miller, Y. Estrin and X. Z. Hu: Scr. Mater. 47 (2002) 441-446.

17) G. Schuster and C. Altstetter: Metall. Trans. A 14A (1983) 2077-2084.

18) M. Gao, S. Chen and R. P. Wei: Metall. Trans. A 23A (1992) 355-370.

19) J. Kuniya, I. Masaoka and R. Sasaki: Corrosion 44 (1988) 21-28.

20) Y. H. Lu, Q. J. Peng, T. Sato and T. Shoji: J. Nucl. Mater. 347 (2005) 52-68.

21) T. Onchi, K. Hide, M. L. Catano and M. Navas: Proc. 10th int. conf. on environmental degradation of materials in nuclear power system-water reactors, ed. by F. P. Ford, G. S. Was and J. L. Nelson, (TMS, 2001).

22) Y. Kaneshima, N. Totsuka, T. Yamada, N. Nakajima and K. Negishi: Proc. 10th int. conf. on environmental degradation of materials in nuclear power system-water reactors, ed. by F. P. Ford, G. S. Was and J. L. Nelson, (TMS, 2001).

23) R. P. Shogan and T. R. Mager: Proc. 10th int. conf. on environmental degradation of materials in nuclear power system-water reactors, ed. by F. P. Ford, G. S. Was and J. L. Nelson, (TMS, 2001).

24) V. Kain, K. Chandra, K. N. Adhe and P. K. De: J. Nucl. Mater. 334 (2004) 115-132.

25) L. W. Tsay, S. C. Yu, S. D. Chyou and D. Y. Lin: Corros. Sci. 49 (2007) 4028-4039.

26) F. P. Ford, D. E. Taylor and P. L. Andresen: Corrosion-assisted cracking of stainless and low-alloy steels in LWR environments, EPRINP-5064M, (1987).

27) L. Peguet, B. Malki and B. Baroux: Corros. Sci. 49 (2007) 199-1948.

28) M. Gao and R. P. Wei: Scr. Metall. Mater. 26 (1992) 1175-1180.

29) L. W. Tsay, M. C. Young and C. Chen: Corros. Sci. 45 (2003) 19851997.

30) L. W. Tsay, M. C. Young, F. Y. Chou and R. K. Shiue: Mater. Chem. Phys. 88 (2004) 348-352. 